\title{
Coupling between genome translation and replication in an RNA virus
}

\author{
Janet E. Novak and Karla Kirkegaard \\ Department of Molecular, Cellular, and Developmental Biology, Howard Hughes Medical Institute, University of Colorado, \\ Boulder, Colorado 80309 USA
}

\begin{abstract}
The replication of poliovirus RNA genomes containing amber mutations was studied to test whether viral proteins provided in trans could rescue the replication of an RNA genome that could not be completely translated itself. Mutants containing amber codons at different positions in the genome displayed vastly different abilities to be rescued by wild-type proteins provided by a helper genome. Amber-suppressing cell lines were used to ensure that the defects in the amber mutants arose from their failure to be translated, not from defects in RNA sequence or structure. An internal region of the poliovirus genome was identified whose translation is required in cis; failure to translate this region was shown to inhibit RNA replication. This coupling between translation and RNA replication could provide a late proofreading mechanism that enables poliovirus, and possibly many other RNA viruses, to prevent the replication of defective genomes.
\end{abstract}

[Key Words: cis action; complementation; RNA replication; RNA stability; poliovirus; translation]

Received March 11, 1994; revised version accepted June 1, 1994.

Poliovirus replicates in the cytoplasm of its host cells, allowing translation and RNA replication to take place in the same cellular compartment and providing the opportunity for close coupling between these processes. Previous experimental observations have led to the hypothesis that poliovirus RNA replication depends on translation of the genome in cis, that is, that translation of a particular genome is required for that RNA genome to replicate, even when viral proteins are provided in trans from a helper genome (Kuge et al. 1986; Collis et al. 1992). A requirement for translation in cis could result either from the preferential cis action of a protein encoded by the genome, or a requirement for the act of ribosomal passage itself in cis.

The poliovirus infectious cycle begins with entry of the virion into a host cell and release of the $7.5-\mathrm{kb}$ polyadenylated viral RNA into the cytoplasm. This RNA encodes all viral proteins in a single open reading frame; it can be translated into a $220-\mathrm{kD}$ polyprotein, which is processed by virus-encoded proteases. The final cleavage products and their locations on the genome are shown in Figure 1A (Kitamura et al. 1981). In addition to being translated and packaged into virions, the viral RNA also serves as template for synthesis of negative strands; these are then templates for positive-strand synthesis. Viral RNA replication requires $3 \mathrm{D}$, the viral RNA-dependent RNA polymerase; other viral proteins known or suspected to be involved in RNA replication are $2 \mathrm{~B}, 2 \mathrm{C}$, $3 \mathrm{~A}, 3 \mathrm{~B}, 3 \mathrm{AB}$, and $3 \mathrm{CD}$ (for review, see Wimmer et al. 1993).

Sequence analysis of defective interfering (DI) particles of poliovirus provided the first evidence that poliovirus
RNA genomes may need to be translated in cis for successful virus replication. DI particles are viral mutants that cannot propagate when they infect a cell alone but can be rescued by coinfection with wild-type virus, which provides the missing or mutant proteins in trans. The genomes of 11 naturally occurring DI particles of poliovirus were sequenced; all contained deletions in the capsid region (Fig. 1A), and all preserved the translational reading frame through the deletion junction (Kuge et al. 1986). Because wild-type virus always coinfected the cells, failure to isolate DI genomes with out-of-frame deletions cannot be explained by a lack of viral proteins. Instead, the absence of out-of-frame deletions could result either from a disadvantage to synthesizing the aberrant truncated proteins that would result, or from a selective advantage to translating the entire open reading frame in cis. The magnitude of any such selective advantage could not, however, be determined, as the DI particles had been propagated over many replicative cycles.

Several deleted genomes of poliovirus have been constructed in vitro to test the idea that translation is required in cis. A genome that contained an in-frame deletion extending into the $2 \mathrm{~A}$-coding region was shown to be capable of replication in the presence of helper viral genome; the deleted region (Fig. 1A) is thus dispensable in cis for RNA synthesis (Collis et al. 1992). Several genomes containing in-frame deletions, but not those containing out-of-frame deletions, were shown to be capable of RNA replication either in the presence or absence of helper genome. If failure to translate the complete open reading frame were the only defect in the out-of-frame mutants, one could conclude that translation of the po- 
A.
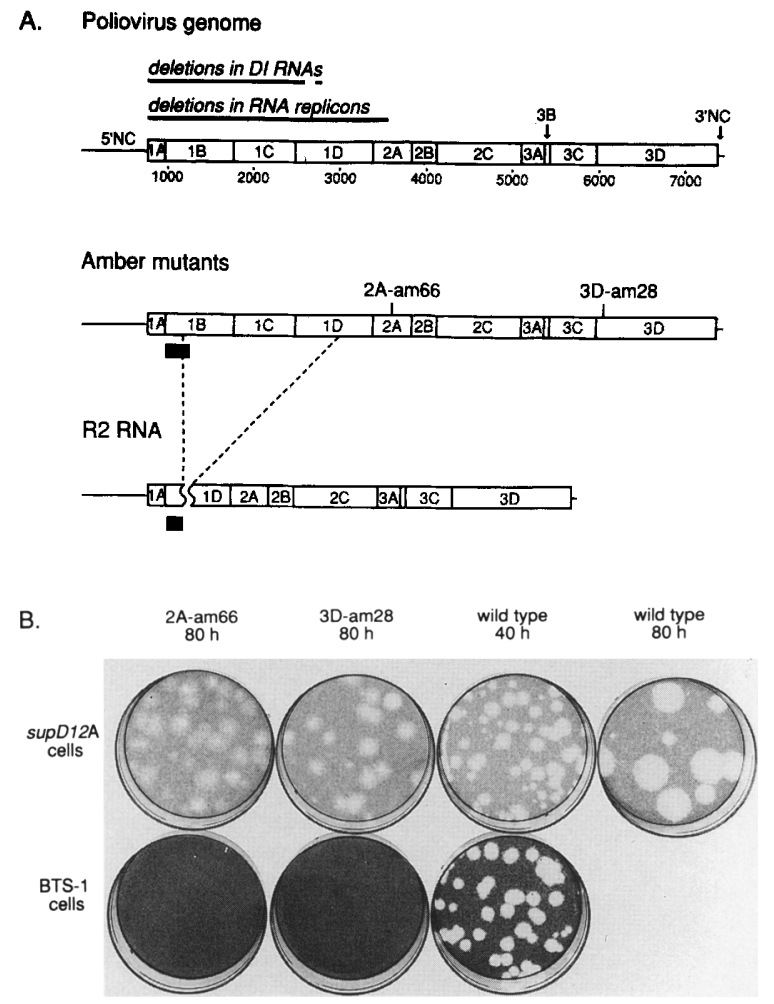

Figure 1. Map position and plaque phenotypes of mutants. $(A)$ The first map shows the wild-type poliovirus RNA genome, with the noncoding regions depicted as lines and the coding regions as open boxes. The proteins $1 \mathrm{~A}, 1 \mathrm{~B}, 1 \mathrm{C}$, and $1 \mathrm{D}$ are capsid proteins; $2 \mathrm{~A}, 3 \mathrm{C}$, and $3 \mathrm{CD}$ are proteases; $3 \mathrm{CD}$ also binds viral positive strands; $3 \mathrm{~B}$ is $\mathrm{VPg}$, a protein found covalently attached to the $5^{\prime}$ end of both positive- and negative-strand RNAs; 3D is the viral RNA-dependent RNA polymerase (for review, see Wimmer et al. 1993). Regions of the genome that can be deleted without eliminating the ability of the RNA to replicate are shown for defective interfering particles (Kuge et al. 1986; Percy et al. 1992) and for functional RNA replicons (Kaplan and Racaniello 1988; Collis et al. 1992). The second map shows locations of the amber mutations used in rescue experiments and the deletion present in R2 (Kaplan and Racaniello 1988). The portions of a negative-sense RNA probe containing nucleotides complementary to poliovirus nucleotides 988-1262 that are protected from RNase treatment by the fulllength and R 2 positive-strand RNAs, respectively, are shown by the solid rectangle under each genome. $(B)$ Plaque assays of wild-type, 2A-am66 and 3D-am28 virus performed on suppressing supD12A and nonsuppressing BTS-1 cells. Plaque assays were incubated at $32.5^{\circ} \mathrm{C}$ for the indicated number of hours and stained with crystal violet after removal of the agar overlays. The turbidity of these plaques is probably attributable to the inhomogeneity of suppressor tRNA expression in the suppressing cell lines (Sedivy et al. 1987).

liovirus genome was required in cis. However, this conclusion is prevented by the possibilities that the truncated proteins created by frameshift mutations were trans dominant or that certain deletions had deleterious effects on RNA structure.
To test the existence of a requirement to translate the poliovirus genome in cis, we studied the replication of amber nonsense mutants of poliovirus in the presence of a helper genome to provide viral proteins in trans. The existence of amber-suppressing (Sedivy et al. 1987) and nonsuppressing primate cell lines allowed us to test the replication of these amber mutants in the presence and absence of their complete translation, while translation of the helper genome was uninterrupted. The results demonstrate that poliovirus RNA replication requires translation in cis through an internal region of the RNA genome.

\section{Results}

Amber mutants $2 A$-am 66 and $3 D$-am 28 replicate in suppressing supD12A cells

BSC-40supD12 cells allow the propagation of amber mutant viruses by expressing an amber-suppressing tRNA that inserts serine at UAG nonsense codons with an efficiency of $50-70 \%$ (Sedivy et al. 1987). For the experiments described in this paper, a clonal derivative of BSC40 supD12, termed supD12A, was used to enhance the visibility of plaques formed by amber mutant polioviruses (see Materials and methods). BTS-1, a closely related cell line that lacks amber-suppressing tRNA genes (Sedivy 1991), was used as the nonsuppressing cell line in the experiments described here.

To construct a mutant poliovirus RNA in which translation of the entire $3^{\prime}$ half of the genome could be conditionally inhibited, codon 66 in the 2A-coding region was changed from a UCU serine to a UAG stop codon, resulting in the mutant 2A-am66 (Fig. 1A). Another amber mutant, 3D-am 28, originally constructed and characterized by Sedivy et al. (1987), was also used in these experiments. $3 \mathrm{D}$-am 28 bears mutations that change codon 28 of the 3D-coding region, an AGU serine codon, to a UAG amber codon (Fig. 1A). Mutant RNAs were transcribed in vitro and transfected into supD12A cells. The transfected cells produced viruses with an amber mutant phenotype: both $2 \mathrm{~A}$-am 66 and $3 \mathrm{D}$-am 28 viruses formed slow-growing, turbid plaques on suppressing cells but did not form plaques on nonsuppressing cells (Fig. 1B). The viability of these amber mutant viruses in amber-suppressing cells shows that the introduced mutations do not confer a defect in the RNA sequence or structure that prevents viral replication.

Efficient rescue of $3 D$-am28, but not $2 A$-am66, by helper RNA in nonsuppressing cells

The helper RNA used to provide poliovirus proteins in trans was R2 (Fig. 1A), a poliovirus RNA derivative with a 1782-nucleotide deletion in the capsid region (Kaplan and Racaniello 1988). Upon transfection of the R2 RNA genome into human cells, RNA replication occurs at a slightly faster rate than that of wild-type poliovirus RNA (Collis et al. 1992; Kaplan and Racaniello 1988). The cap- 
sid region deletion, however, prevents R2 from forming infectious particles.

To test the extent to which $3 \mathrm{D}$-am 28 virus production can be rescued by proteins expressed from the $\mathrm{R} 2$ helper genome, 3D-am28 RNA was transfected with and without R2 helper RNA into supD12A and BTS-1 cells. The cotransfection efficiency, or fraction of cells transfected with one type of RNA molecule that also took up another, was determined to be $>99 \%$ under these conditions (see Materials and methods). The amber mutant virus yield from transfections of 3D-am28 and R2 RNAs was determined subsequently by plaque assay of virus stocks prepared from the transfected cells. Figure 2 and Table 1 show the results of one such experiment: 3Dam28 RNA, when transfected alone or when cotransfected with R2 RNA into supD12A cells, gave rise to

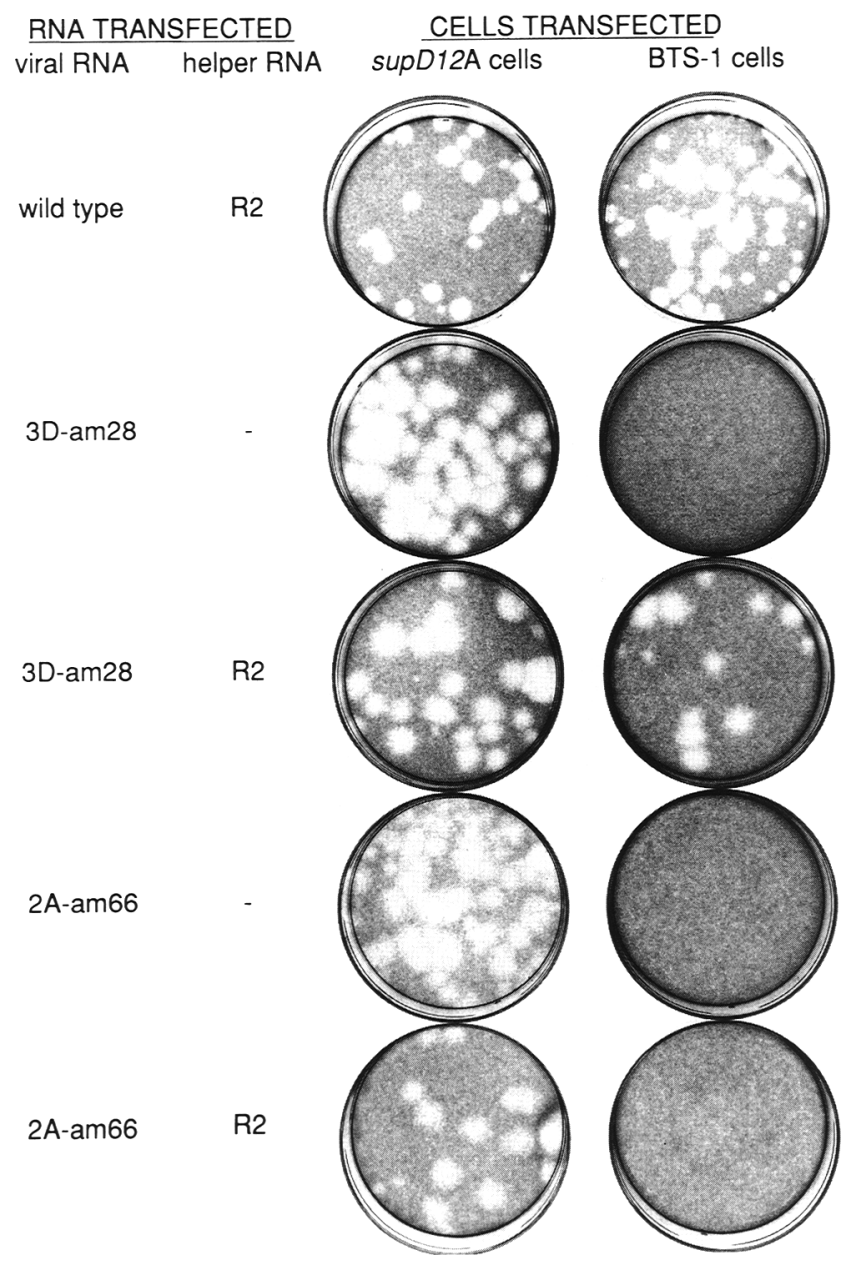

Figure 2. Extent of rescue of $3 \mathrm{D}$-am 28 and $2 \mathrm{~A}$-am66 virus by cotransfected R2 RNA. Suppressing supD12A and nonsuppressing BTS-1 cells were transfected with the indicated RNAs incubated at $32.5^{\circ} \mathrm{C}$. The resulting virus stocks were titered on suppressing supD12A cells as shown. The same dilution was used for all virus stocks except wild-type stocks, which were diluted 10-fold more. In most cases, cotransfections with R2 RNA reduce the virus yield (Kaplan and Racaniello 1988).
Table 1. Rescue of $3 D$-am 28 and $2 A$-am 66 virus production in nonsuppressing cells by cotransfection with $R 2$ helper RNA

\begin{tabular}{lcc}
\hline & \multicolumn{2}{c}{ Virus detected $^{\mathrm{a}}$ following transfection into } \\
\cline { 2 - 3 } RNA transfected & supD12A cells & BTS- $1 \mathrm{cells}$ \\
\hline Wild type & $280,000 \mathrm{wt}$ & $1,150,000 \mathrm{wt}$ \\
& $590,000 \mathrm{wt}$ & $780,000 \mathrm{wt}$ \\
Wild type + R2 & $76,000 \mathrm{wt}$ & $140,000 \mathrm{wt}$ \\
& $34,000 \mathrm{wt}$ & $77,000 \mathrm{wt}$ \\
3D-am28 & $9000 \mathrm{am}$ & 0 \\
& $7000 \mathrm{am}$ & 0 \\
3D-am28 + R2 & $2300 \mathrm{am}$ & $800 \mathrm{am}$ \\
& & $(840 \mathrm{total})$ \\
& $2600 \mathrm{am}$ & $1130 \mathrm{am}$ \\
& $(2700 \mathrm{total})$ & $(1160 \mathrm{total})$ \\
2A-am66 & $8500 \mathrm{am}$ & 0 \\
& $6800 \mathrm{am}$ & $3 \mathrm{am}$ \\
2A-am66 + R2 & $1080 \mathrm{am}$ & $(20 \mathrm{total})$ \\
& & $0 \mathrm{am}$ \\
& $920 \mathrm{am}$ & $(10 \mathrm{total})$ \\
\hline
\end{tabular}

${ }^{a}$ Virus yield from transfected supD12A and BTS-1 cells is given as PFU/plate, as determined by plaque assay on supD12A cells. Turbid plaques characteristic of amber mutant virus are designated am. Nonamber revertant or recombinant virus, which could be distinguished by forming clear plaques on both supD12A and BTS-1 cells, are not included in the amber mutant virus yield but are included in the total yield, where different. Clear plaques characteristic of wild-type virus are marked wt. The results of duplicate RNA transfections are shown. The limit of detection was $2.5 \mathrm{PFU} /$ plate; multiple plates were assayed in some cases.

amber mutant viruses. As expected, when $3 \mathrm{D}$-am 28 RNA was transfected alone into nonsuppressing BTS-1 cells, no virus was formed. However, when $3 \mathrm{D}$-am 28 and R2 RNA were cotransfected into nonsuppressing BTS-1 cells, amber mutant virus was formed. The extent of rescue was calculated (see Materials and methods) to compare the growth of $3 \mathrm{D}$-am 28 virus in cotransfections with R2 RNA under conditions in which the 3D-am28 RNA could not be fully translated (BTS-1 cells) to conditions in which complete 3D-am28 RNA translation was restored (supD12A cells). For the experiment shown, the percentage rescue of $3 \mathrm{D}$-am 28 by cotransfected $\mathrm{R} 2$ RNA was $20 \%$ (Table 1; Fig. $2 \mathrm{~B}$ ); the average from such experiments was $16 \%$. Thus, the product of the $3 \mathrm{D}$-coding region, the poliovirus RNA-dependent RNA polymerase, can be provided in trans, and there appears to be only a modest advantage for a poliovirus genome to be translated in cis downstream of the 3D-am 28 mutations.

When similar experiments were performed with $2 \mathrm{~A}$ am66 RNA, quite different results were obtained (Fig. 2; Table 1). Whereas cotransfection of $2 \mathrm{~A}-\mathrm{am} 66$ and R2 RNAs into suppressing cells gave rise to $10^{3}$ plaqueforming units (PFU)/plate of amber mutant virus, cotransfection of these RNAs into nonsuppressing cells gave rise to only a very low yield of amber mutant virus. The percentage rescue, determined as described in $\mathrm{Ma}$ - 
terials and methods, was $0.08 \%$ in this experiment $\mathrm{Ta}$ ble 1) and averaged $0.12 \%$. Diminished replication of $2 \mathrm{~A}$ am66 was not attributable to trans-dominance of the amber mutant virus in nonsuppressing cells (see below). Therefore, the low percentage rescue of $2 \mathrm{~A}$-am $66 \mathrm{dem}$ onstrates a strong but not absolute need to translate the poliovirus genome in cis.

\section{Rescue or recombination?}

It is possible that the apparent rescue of $3 \mathrm{D}$-am 28 and $2 \mathrm{~A}$-am 66 viruses resulted from recombination between the amber mutant and the R2 helper RNAs rather than from complete RNA synthesis from the amber mutant RNA template. Recombination in poliovirus occurs by template switching of the viral replication complex during negative-strand synthesis (Kirkegaard and Baltimore 1986). If template switching occurred between one of the amber mutations and the $3^{\prime}$ end of the genome, an amber mutant viral genome could be synthesized whose replication had actually initiated on the R2 helper genome.

To determine whether the low amount of $2 \mathrm{~A}$-am 66 virus rescued by R2 RNA in nonsuppressing cells (Table 1) arose from recombination, additional mutations were introduced as markers. The marker mutations were a cluster of five single-nucleotide substitutions termed 3D-114 (Diamond and Kirkegaard 1993). The predicted consequences of recombination events between 2Aam66-3D-114 viral RNA and R2 helper RNA are shown in Figure 3A. Because recombination frequencies in picornaviruses are roughly proportional to distance $(\mathrm{McCa}-$ hon et al. 1977; Jarvis and Kirkegaard 1992), the most likely recombination events would be those that occurred in the largest interval, interval a. The amber mutant viruses that arose by recombination in interval a would have lost the 3D-114 mutations, whereas the amber mutant viruses that arose from rescue of $2 \mathrm{~A}$-am66 would retain the $3 \mathrm{D}-114$ mutations.

Amber mutant viral progeny produced from cotransfection of 2A-am66-3D-114 and R2 RNAs into BTS-1 nonsuppressing cells were tested for the presence of the 3D-114 mutations. The amber mutant progeny arose, as expected, at a very low frequency. Five nonsibling progeny viruses were obtained and found by RNase protection to contain the 3D-114 mutations (Fig. 3C, lanes $5-9)$. Thus, it is unlikely that the amber mutant viral progeny from this transfection resulted from recombination between the 2A-am66-3D114 and R2 helper RNAs. The reciprocal experiment, cotransfecting $2 \mathrm{~A}$-am 66 and R2-3D-114 RNAs (Fig. 3B), showed that none of five amber mutant progeny contained the 3D-114 markers that would indicate recombination in interval a (Fig. 3C, lanes 10-14). Therefore, the low level of amber mutant virus that resulted from these cotransfections was not attributable to recombination but to true rescue of $2 \mathrm{~A}$ am66 RNA synthesis.

The recombination interval between the $2 \mathrm{~A}$-am 66 mutations and the 3 ' end of the genome, where negativestrand synthesis is initiated, is greater than the interval between the 3D-am28 mutations and the $3^{\prime}$ end of the
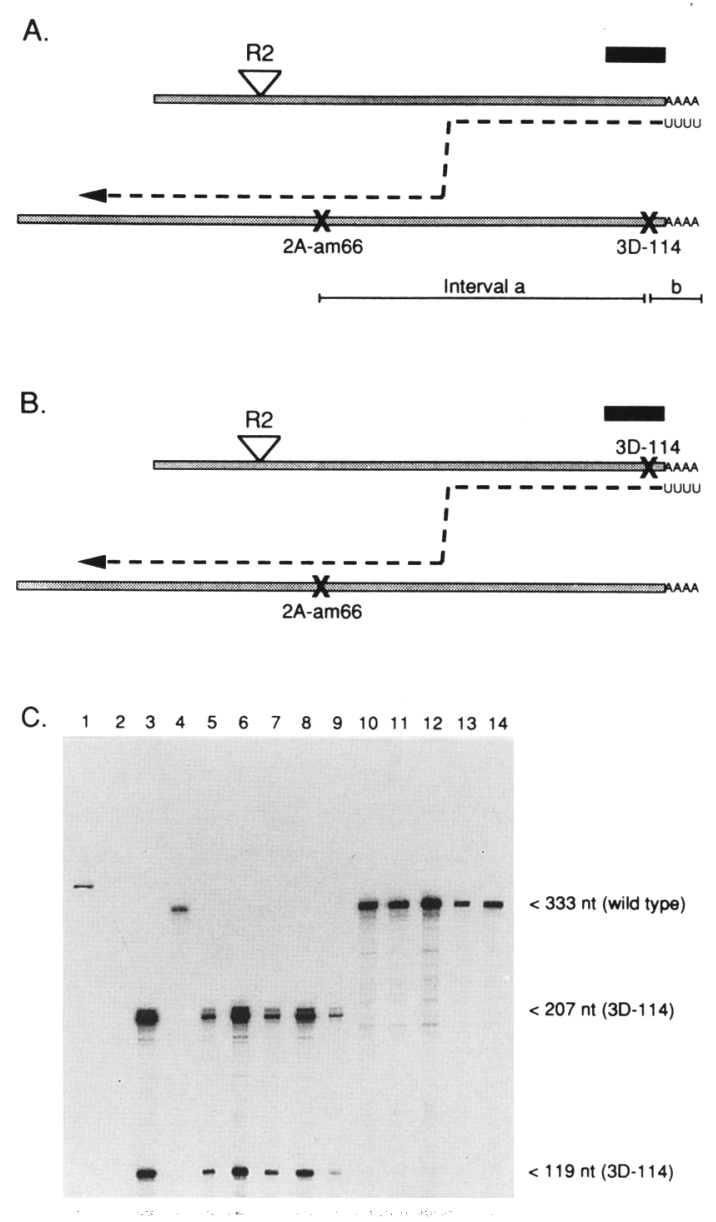

Figure 3. Analysis of genetic markers in $2 \mathrm{~A}$-am 66 viruses from cotransfections. (A) Cotransfection between 2A-am66-3D114 viral and R2 helper RNAs. Rescued 2A-am66 virus should still contain the 3D-114 marker, whereas a product of recombination in interval a (3700 nucleotides) should not contain the 3D114 mutations. Interval $\mathrm{b}$ is 250 nucleotides long, assuming a poly(A) tail of 75 nucleotides (Spector and Baltimore 1974). The solid rectangle shows the location of the wild-type RNase protection probe used to test for the presence of the 3D-114 mutations, in which nucleotides 7263-7269 are altered from AAGAAGA to CCGCGGC (Diamond and Kirkegaard 1993). (B) Cotransfection between 2A-am66 viral and R2-3D-114 helper RNAs. A rescued $2 \mathrm{~A}$-am 66 virus would not bear the $3 \mathrm{D}-114$ mutations and a product of recombination in interval a would. (C) RNase protection experiment to test whether progeny virus arising from cotransfection of BTS-1 nonsuppressing cells resulted from rescue or recombination. (Lane 1) Labeled RNA probe containing sequences complementary to nucleotides. 7056-7388 of the poliovirus positive strand and additional polylinker sequences. (Lanes 2-14) RNase digestion of labeled probe following hybridization to the following cytoplasmic RNAs. (Lane 2) Uninfected cell RNA; (lane 3) RNA from 2A-am66-3D114-infected cells; (lane 4) RNA from 2A-am66-infected cells; (lanes 5-9) RNA prepared from five different isolates of virus recovered from cotransfecting $2 \mathrm{~A}$-am66-3D-114 virus and $\mathrm{R} 2$ helper RNAs into BTS-1 cells; (lanes 10-14) RNA prepared from five different isolates of virus recovered from cotransfecting $2 \mathrm{~A}$ am66 viral and R2-3D-114 helper RNAs into BTS-1 cells. 
genome. Thus, recombination events that generate amber mutant viral RNAs are less likely between $3 \mathrm{D}$-am 28 virus and cotransfected R2 RNAs than between $2 \mathrm{~A}$ am66 and R2 RNAs. We conclude that the production of $3 \mathrm{D}$-am 28 virus following cotransfection of $3 \mathrm{D}$-am 28 and R2 RNAs in nonsuppressing cells (Fig. 2; Table 1) also resulted from true rescue, and not from recombination.

Rescue of 3D-am28, but not 2A-am66, can be observed at the level of RNA replication

To determine whether RNA replication is the process requiring translation in cis, we monitored the accumulation of 2A-am66 and 3D-am28 RNAs in the presence of R2 helper RNA in suppressing and nonsuppressing cells. At various times post-transfection, the amounts of positive-sense amber mutant and R2 RNA were monitored by RNase protection. Hybridization of a 323-nucleotide RNA probe to full-length viral RNA should protect a 275-nucleotide RNA fragment, whereas R2 RNA should protect only 187 nucleotides of the probe (Fig. 1A).

Time courses of amber mutant and R2 accumulation following RNA transfection into suppressing and nonsuppressing cells are shown in Figure 4. In suppressing supD12A cells, accumulation of each RNA genome
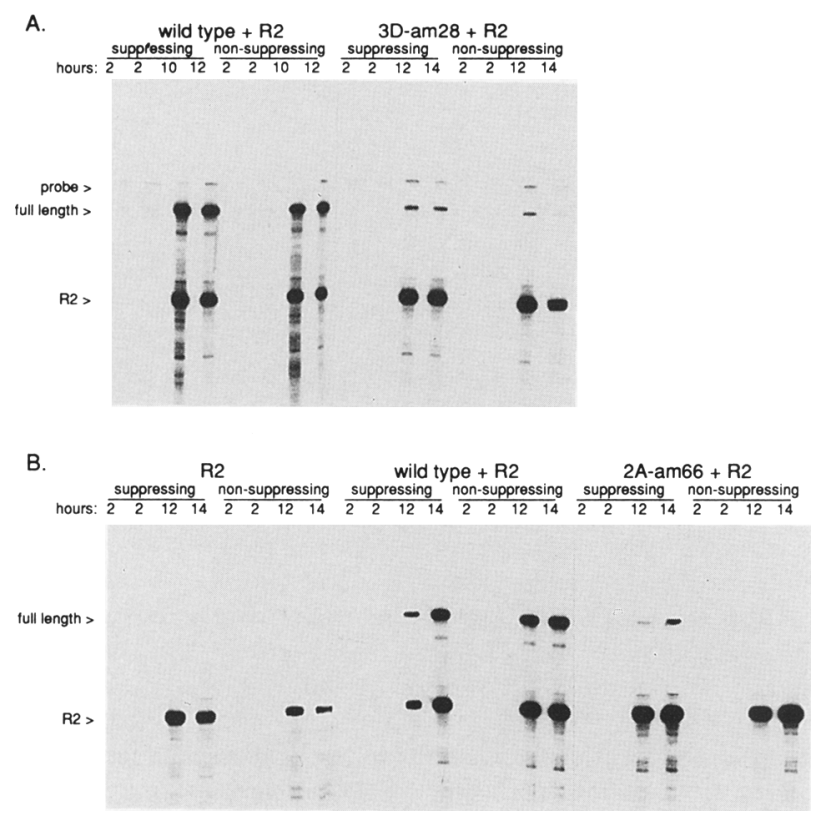

Figure 4. Accumulation of viral and helper RNAs following cotransfection. (A) Wild-type, 3D-am28, and R2 RNAs were transfected into suppressing (supD12A) cells and nonsuppressing (BTS-1) cells as marked. (B) Wild-type, 2A-am66, and R2 RNAs. Time courses are shown; the 2-hr time points were taken in duplicate. Cytoplasmic RNAs were subjected to RNase protection, using a labeled RNA probe complementary to nucleotides $988-1262$ of the poliovirus positive strand. RNA standards were probed and quantified in parallel to ensure that the RNase protection signals were proportional to the amount of viral RNAs probed. transfected was observed. Neither 3D-am28 nor 2Aam66 RNAs increased in amount after transfection alone into nonsuppressing BTS-1 cells (not shown). However, when 3D-am28 RNA was cotransfected into BTS-1 cells with R2 helper RNA, both RNAs accumulated over time, indicating that $\mathrm{R} 2 \mathrm{RNA}$ rescued the ability of $3 \mathrm{D}$ am28 RNA to be replicated (Fig. 4A). In contrast, R2 RNA did not detectably rescue accumulation of $2 \mathrm{~A}-$ am66 RNA (Fig. 4B). Because of the background contributed by input transfected RNA in this assay, the limit of detection of RNA accumulation would correspond to $10-20 \%$ rescue. In this experiment, rescue of $2 \mathrm{~A}$-am 66 virus production was $0.1 \%$, an extent of rescue that clearly would not have been detected in the RNase protection experiment. The simplest hypothesis is that RNA accumulation and virus production were rescued to the same, very low, extent. Regardless, failure to translate in cis reduced accumulation of 2A-am66 RNA at least fivefold, and thus translation of CTR sequences in cis is required for efficient poliovirus RNA replication.

The experiments shown in Figure 4 also demonstrated that 3D-am 28 and 2A-am66 RNAs are not dominant in trans over R2 RNA replication. R2 RNA accumulated to about the same levels when cotransfected with either wild-type, 2A-am66, or 3D-am 28 RNA. Thus, the observed defects of amber mutants in RNA accumulation and virus accumulation in BTS-1 cells in the presence of helper RNA were cis dominant, and not trans dominant.

Requirement for translation in cis is not attributable to an increase in RNA stability conferred by translation

One possible mechanism for the observed dependence of viral RNA replication on translation in cis is that in the absence of complete translation, amber mutant viral RNAs are rapidly degraded in nonsuppressing cells. Destabilization of incompletely translated RNAs has been observed for various RNAs in a variety of organisms, although the opposite effect has also been observed with other mRNAs (for review, see Peltz et al. 1991). The stability of wild-type, 3D-am28, and 2A-am66 viral RNAs was tested after infection of nonsuppressing BTS-1 cells. To inhibit new viral RNA synthesis in the wild-type-infected cells, $2 \mathrm{~mm}$ guanidine was added, a specific inhibitor of picornaviral RNA synthesis /Caliguri and Tamm 1968). The decrease in the amount of viral RNA over time was quantified by RNase protection. The amber mutant RNAs appeared, if anything, more stable than the wild-type RNA (Fig. 5). To exclude the possibility that guanidine itself affects RNA stability, we tested the stability of 3D-am 28 RNA in BTS-1 cells in the absence of guanidine, as well as in its presence. No difference in the stability of 3D-am 28 RNA was observed (Fig. 5). Therefore, the apparent stability of 3Dam 28 and $2 \mathrm{~A}$-am66 RNAs did not result from guanidine treatment, and the requirement of poliovirus RNA synthesis for translation in cis does not result from an in- 


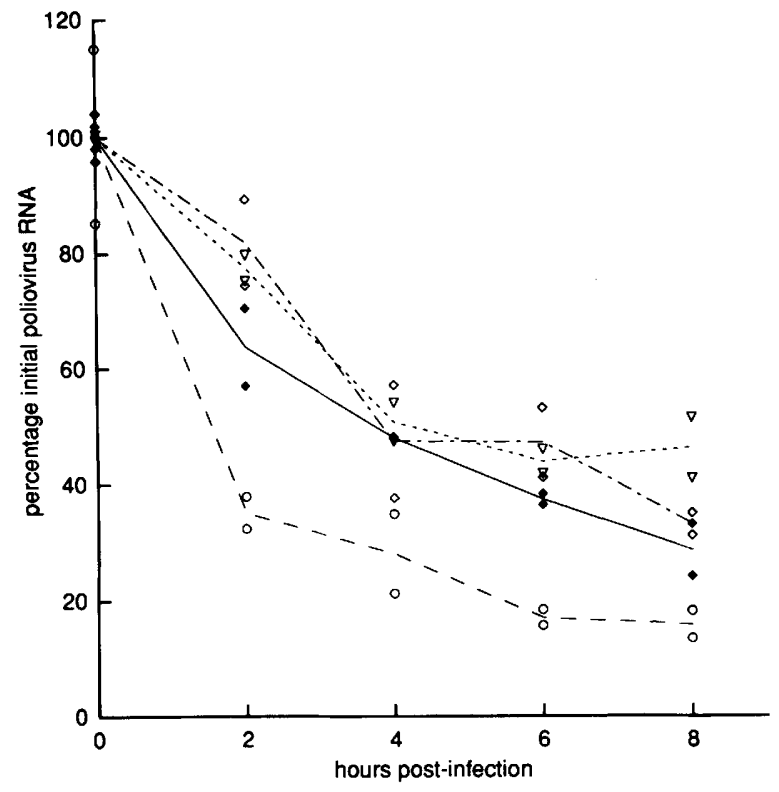

Figure 5. Stability of wild-type, $3 \mathrm{D}$-am 28 , and $2 \mathrm{~A}$-am 66 viral RNAs. Nonsuppressing BTS-1 cells were infected with the viruses indicated at $32.5^{\circ} \mathrm{C}$ in the presence or absence of $2 \mathrm{~mm}$ guanidine. Cytoplasmic RNAs were prepared and subjected to RNase protection. Amounts of poliovirus RNA were normalized to the amount of $18 \mathrm{~S}$ rRNA in each sample (Materials and methods). Amounts of wild-type RNA (O), 2A-am66 RNA ( $\nabla)$, and $3 \mathrm{D}$-am28 RNAs from infections with $(\diamond)$ and without $(\diamond)$ guanidine were plotted as the percentage of the amount of that RNA present at $0 \mathrm{hr}$ postinfection.

crease in RNA stability conferred to translated viral RNAs.

\section{Viral RNA synthesis does not require continuous translation}

One set of explanations of coupling between translation and RNA replication posits that the synthesis of new RNA strands requires newly synthesized viral proteins, or that positive-strand RNAs must be translated frequently for RNA synthesis to continue. In either case, stopping translation in the middle of the infectious cycle should inhibit RNA replication rapidly. In contrast, continuation of RNA replication for more than a short time after translational inhibition would rule out these possibilities. Although it has been shown that RNA synthesis can continue at a significant but reduced rate after treatment with inhibitors of protein synthesis, these experiments did not distinguish between positive- and negative-strand synthesis (Levintow et al. 1962; Ehrenfeld et al. 1970|. Therefore, we chose to monitor the effects of inhibiting protein synthesis on positive- and negativestrand synthesis separately.

The accumulation of both positive- and negativestrand poliovirus RNA after treatment with puromycin was monitored (Fig. 6). Poliovirus-infected CV1 cells were either treated with $800 \mu \mathrm{M}$ puromycin or with no

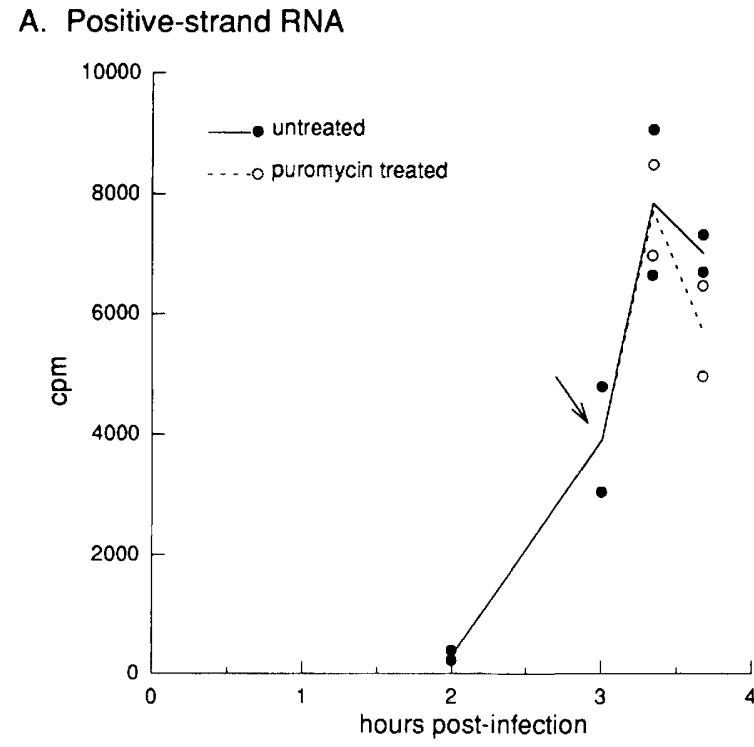

B. Negative-strand RNA

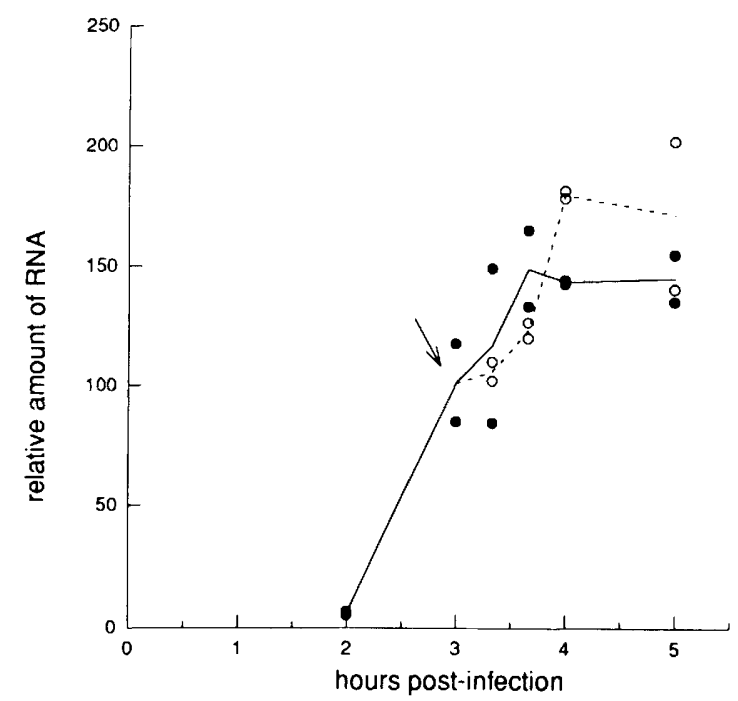

Figure 6. Effect of protein synthesis inhibition on poliovirus positive- and negative-strand synthesis. (A) Accumulation of positive strands after puromycin treatment. CVl cells were infected with poliovirus at an m.o.i. of 70 ; at $3 \mathrm{hr}$ postinfection at $37^{\circ} \mathrm{C}, 800 \mu \mathrm{M}$ puromycin was added to half of the plates. At various times postinfection, duplicate treated and untreated plates were harvested for preparation of cytoplasmic RNAs. RNase protection was performed, using a probe complementary to nucleotides $1-388$ of the poliovirus positive strand to determine the amount of positive-strand RNA at each time. A series of RNA standards probed in parallel showed that the RNase protection signals detected in the experiment were proportional to the amounts of poliovirus RNA in the samples. The arrow denotes the time of puromycin addition. $(B)$ Negative-strand RNAs in the same cytoplasmic RNA samples were quantified using two cycles of RNase protection. The probe contained nucleotides $7056-7388$ of the poliovirus positive strand. Poliovirus-infected cells were used to develop standard curves (see Materials and methods). Units shown are equivalent to RNA from $10^{3}$ poliovirus-infected cells. 
drug at $3 \mathrm{hr}$ postinfection. Cytoplasmic RNAs prepared at various times post-transfection were subjected to RNase protection to determine the amount of positivestrand poliovirus RNA present. To ensure that the signal obtained from the RNase protection experiment reflected the amount of positive-strand RNA accurately in the samples, a dilution series of RNA from poliovirusinfected cells was subjected to the same treatment; in the range of RNase protection signals shown, the amount of protected RNA was proportional to the amount of positive-strand RNA present in the sample (not shown). As shown in Figure 6A, positive-strand RNA continued to accumulate for $30 \mathrm{~min}$ after the addition of puromycin.

To test for negative-strand synthesis after puromycin treatment, cytoplasmic RNAs from untreated and puromycin-treated cells were probed for negative-strand RNAs. A two-cycle RNase protection protocol was used (Novak and Kirkegaard 1991); this method allows the sensitive and quantitative detection of negative strands despite the excess unlabeled positive strands present in the cytoplasmic extracts. This experiment (Fig. 6B) showed that negative-strand synthesis continued for at least $1 \mathrm{hr}$ after puromycin addition. Because this is much longer than the estimated $45 \mathrm{sec}$ needed to complete the synthesis of a viral RNA molecule (Baltimore 1969), initiation as well as elongation of viral RNA molecules can continue in the presence of puromycin.

Similar experiments were performed with cycloheximide, which inhibits translation by a different mechanism (for review, see Pestka 1971). The extent of translational inhibition of both these compounds was determined by measuring the incorporation of $\left[{ }^{35} \mathrm{~S}\right] \mathrm{me}$ thionine into protein in untreated and drug-treated poliovirus-infected CV1 cells from 5 to $35 \mathrm{~min}$ after the drugs were added. Cells treated with $50 \mu \mathrm{g} / \mathrm{ml}$ of cycloheximide and with $800 \mu \mathrm{M}$ puromycin showed a $92.6 \%$ and a $99.5 \%$ reduction in labeled protein, respectively. When poliovirus RNA synthesis was monitored after the addition of $50 \mu \mathrm{g} / \mathrm{ml}$ of cycloheximide at $3 \mathrm{hr}$ postinfection, both positive- and negative-strand accumulation continued for at least $30 \mathrm{~min}$ (data not shown). Therefore, cells infected with wild-type poliovinus and treated with either cycloheximide or puromycin in the middle of the infectious cycle were able to continue synthesizing both positive- and negative-sense RNAs. Continuation of RNA synthesis therefore does not depend on the viral RNA's continued association either with ribosomes or with nascent peptides.

\section{Discussion}

The quantitative advantage of translating the poliovirus genome in cis

Mutant poliovirus 2A-am66, with an amber nonsense codon in the 2A-coding region, was used to test for a requirement to translate the poliovirus genome in cis. Mutant 2A-am66 did not produce virus efficiently in nonsuppressing cells, even when cotransfected with a helper RNA to provide viral proteins in trans. The poor replication of $2 \mathrm{~A}$-am66 was not trans dominant over replication of the R2 helper RNA. Therefore, the amber mutation in $2 \mathrm{~A}$-am 66 virus is strongly cis dominant. The most frequent explanation for cis dominance is that the mutation disrupts a site required in the genome itself. With 2A-am66, however, this explanation was excluded by the ability of the virus to grow in amber-suppressing cells. Thus, the cis dominance of $2 \mathrm{~A}$-am66 in BTS-1 cells results from the failure of $2 \mathrm{~A}$-am 66 to have its entire coding region translated in nonsuppressing cells. The average extent of rescue of $2 \mathrm{~A}$-am 66 virus by $\mathrm{R} 2$ helper RNA in nonsuppressing cells, to $0.12 \%$ of its yield under similar conditions in amber-suppressing cells, indicates an $\sim 800$-fold advantage to poliovirus when it can translate its entire coding region in cis.

\section{The CTR region of the poliovirus genome}

Another amber mutant, 3D-am28, whose translation terminates in the 3D-coding region 2484 nucleotides downstream of the termination site in 2A-am66, showed a much higher extent of rescue, averaging $16 \%$. That a mutant able to translate only the first 27 amino acids of $3 \mathrm{D}$, the viral RNA-dependent RNA polymerase, can be rescued fairly effectively argues that all functions of $3 \mathrm{D}$ required for virus production in infections started by RNA transfection can be provided in trans. One caveat to this conclusion is that a low level of translational readthrough of the amber mutation in nonsuppressing cells may satisfy the requirement to translate in cis in the presence of large amounts of complementing protein from helper viral RNA. However, no amber mutant virus was produced in nonsuppressing cells in the absence of helper RNA, arguing that the amount of translational readthrough is extremely low. That some $3 \mathrm{D}$ functions could be provided in trans was shown previously by the ability of RNA synthesis of a 3D mutant to be rescued by wild-type or mutant viruses (Charini et al. 1991). The existence of two 3D mutants that could not be complemented (Bernstein et al. 1986; Trono et al. 1988) is probably attributable to cis-dominant RNA defects in the mutant genomes. $3 \mathrm{CD}$, which has functions distinct from those of 3C and 3D (Ypma-Wong et al. 1988; Andino et al. 1993), probably also functions in trans; the truncated protein encoded in cis by 3D-am 28 seems unlikely to retain any $3 \mathrm{CD}$ functions.

The different extents of rescue of $2 \mathrm{~A}-\mathrm{am} 66$ and $3 \mathrm{D}$ am 28 viruses, together with earlier reports, begin to define a region of the poliovirus genome that we term the CTR (cis-translation required) region. This region is not likely to include sequences that can be deleted in replicating RNAs. Because such deletions extend from the $1 \mathrm{~A}$-coding region to the first 45 codons of the $2 \mathrm{~A}$ region (Fig. 1A; Collis et al. 1992), the CTR region is likely to lie $3^{\prime}$ of codon 45 of the $2 \mathrm{~A}$ region (Fig. 7). The cis dominance of 2A-am66 in nonsuppressing cells demonstrates a need to translate at least part of the region $3^{\prime}$ of the 2A-am66 mutations in cis. Because translation of the 1308 nucleotides $3^{\prime}$ of the amber codon in $3 \mathrm{D}$-am28 pro- 


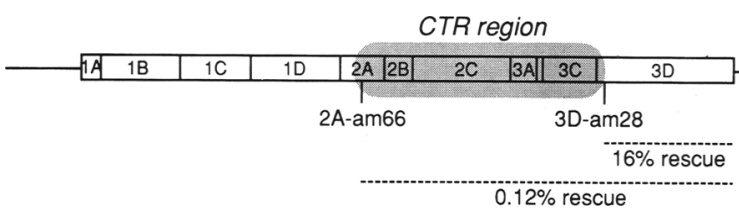

Figure 7. The CTR region of the poliovirus genome, in which translation is strongly required in cis, is located somewhere within the shaded area. Indicated below the genome map are the parts of the coding region that $2 \mathrm{~A}$-am 66 and 3D-am 28 viruses are unable to translate in nonsuppressing cells and the average percentages of rescue from two independent rescue experiments such as that shown in Fig. 2 .

vided only an approximately sixfold advantage to the virus, these sequences have not been included in the CTR region. If the mechanism of requiring translation in cis is attributable to a cis-acting protein, then the boundaries of the CTR region are likely to correspond to coding region boundaries. If, however, ribosome transit itself through the CTR region is required in cis, the CTR boundaries will not necessarily correspond to coding region boundaries. The shaded area in Figure 7 represents the maximum possible extent of the CTR region.

The amount of nonsense suppression of an amber mutation can influence the measured extent of rescue of that amber mutant. If RNA context effects caused an amber mutant to have weak translational readthrough in suppressing cells, then the calculated percentage of rescue of that mutant in nonsuppressing cells would be artificially high. It seems likely, however, that the very different extents of rescue seen for 3D-am28 and 2Aam66 result from a strong requirement to translate the region between the two mutations in cis and much less need to translate the 3D-coding region in cis. Thus, the
CTR sequences are most likely to lie between the mutations as shown in Figure 7.

\section{Possible mechanisms for the requirement of the CTR region to be translated in cis}

Rescue of RNA accumulation of 2A-am66 and 3D-am28 was investigated to test which process in the infectious cycle requires translation in cis. Mirroring the effects of translation in cis on virus production, 2A-am66 RNA synthesis was not rescued detectably by helper RNAs in nonsuppressing cells, whereas $3 \mathrm{D}$-am 28 RNA synthesis could be rescued efficiently (Fig. 4). Thus, viral RNA replication depends on translation of the CTR region in cis. It is not yet known whether this dependence applies to negative-strand synthesis, positive-strand synthesis, or both.

A requirement to translate in cis could be attributable to a cis requirement for either the translation product encoded in the CTR region, or for the act of translation itself through this region. A poliovirus protein might be restricted to cis action by one of several mechanisms. For example, one or more viral proteins might function in ongoing viral RNA synthesis only when nascent or newly synthesized. An analogous mechanism is the cis action of nascent $\beta$-tubulin protein, which affects the stability of only the RNA from which it is translated (Yen et al. 1988). Such a possibility was excluded by the ability of viral RNA synthesis to continue in the presence of protein synthesis inhibitors (Fig. 6). However, it remains possible that a cis-acting protein is required in nascent or newly synthesized form, not for every round of RNA synthesis but only to establish a given RNA as a template, or only early in the infectious cycle. As shown in Figure 8A, such a cis-acting protein might interact with the positive strand from which it is being translated

\section{Protein Required in Cis}

A. Newly synthesized Protein is Required for Template Establishment

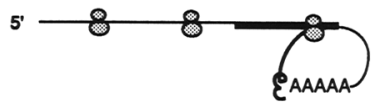

B. Protein's Diffusion or Integrity is Restricted

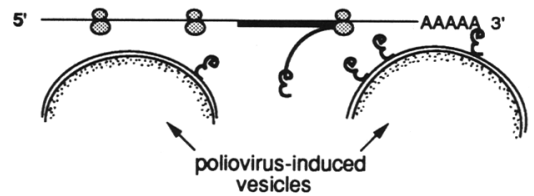

E. Ribosomes Directly Affect Association of Proteins or Cellular Structures with Viral RNA

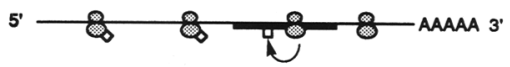

Figure 8. Potential mechanisms for dependence on translation in cis. The poliovirus RNA genome is shown as a line terminating in poly $(\mathrm{A})$; the heavy bold portion denotes the CTR region; cis-acting viral proteins translated from the CTR region are shown in bold. Ribosomes are depicted as two shaded ovals. In $E$, a ribosome-associated factor is represented by a small open square. 
to enable that RNA to be a template for negative-strand synthesis.

Another possibility is that a viral protein acts preferentially in cis because of a restriction in its ability to diffuse to another template RNA (Fig. 8B). Diffusion could be limited by the protein's affinity for a localized structure. For example, the affinity of the $\phi X 174$ cisA protein for the cell membrane is thought to be responsible for its preferential cis action (Francke and Ray 1972). Figure $8 \mathrm{~B}$ shows binding to membranes restricting the diffusion of a viral protein; several poliovirus proteins and viral RNA synthesis are found associated with cytoplasmic membrane surfaces (Bienz et al. 1990). The diffusion of a protein could also be limited by its stability; the short half-life of IS903 transposase restricts this protein to acting in cis (Derbyshire et al. 1990). In the case of poliovirus, a short-lived intermediate in processing of the polyprotein could be present at high concentration only near the RNA from which it was translated.

A final possibility to explain the cis action of a viral protein would obtain if a viral RNA molecule were only transiently competent for both translation and replication. Thus, the RNA molecule from which a protein was translated would be one of the few RNA molecules in the vicinity that was available at that time as a template for RNA synthesis, and the effect would be preferential cis action of the translation products of each RNA molecule. This mechanism would be analogous to the expression of IS10 transposase and the availability of the DNA for transposition, which are simultaneously optimal only when the transposon DNA is transiently hemimethylated (Kleckner 1990).

The existence of cis-dominant mutants whose lesions map to 2B (Bernstein et al. 1986; Li and Baltimore 1988; Johnson and Sarnow 1991), 3A (Giachetti et al. 1992), 3C (Andino et al. 1990), and 3D (Bernstein et al. 1986; Trono et al. 1988/ has been, in some cases, cited as evidence for the cis action of each of these proteins. However, none of these experiments excluded the possibility that the mutations introduced functional defects into the RNA sequence or structure. As noted above, cis-dominant mutations have been found in the coding region of $3 \mathrm{D}$ (Bernstein et al. 1986; Trono et al. 1988), whereas we have shown here that 3D acts in trans. It is thus difficult to know which cis-dominant mutations in the poliovirus genome, if any, identify cis-acting proteins. Complementable mutants have been described in $2 \mathrm{~A}, 2 \mathrm{C}, 3 \mathrm{~A}$, 3C, and 3D (Bernstein et al. 1986; Li and Baltimore 1988; Dewalt and Semler 1989; Charini et al. 1991), arguing that at least one function of these peptide sequences can be provided in trans.

It is possible that the act of ribosomal passage through the CTR region could itself be responsible for the requirement for translation of the poliovirus genome in cis. The data shown in Figure 6 argue that continuous ribosomal passage is not necessary for a positive-strand RNA molecule to remain a template throughout the infectious cycle. However, ribosomal passage through the CTR region may allow that RNA to be competent for later use as a template. One possible mechanism is an effect of ribosomal passage on RNA stability; failing to translate the poliovirus RNA in cis could inhibit RNA replication because incompletely translated templates were degraded. This possibility was excluded, however, by the data shown in Figure 5.

Remaining possibilities for effects of ribosomal passage in cis on RNA replication are shown in Figure 8. Ribosomal passage could alter the RNA structure in the CTR region to facilitate negative-strand synthesis (Fig. 8D). In MS2 phage, ribosome passage through the coat protein cistron destabilizes an RNA structure, thus derepressing lysis protein synthesis (Berkhout et al. 1987). Another possible mechanism is that a ribosome-associated protein or subcellular structure, required for RNA synthesis, can be obtained or used by the viral genome only while ribosomes pass through the CTR region (Fig. 8E). An analogous situation would be the dependence of $\mathrm{N}$-dependent transcription termination in $\lambda$ phage on the $\mathrm{N}$-utilization site (nut); passage of the host RNA polymerase-NusA complex through the nut site facilitates complex formation with the $\lambda \mathrm{N}$ protein (Nodwell and Greenblatt 1991).

\section{Why should an RNA virus require translation in cis?}

By any mechanism, the dependence of poliovirus RNA replication on translation in cis may serve to prevent amplification of defective interfering particle genomes and other defective genomes. In contrast to some other RNA viruses, poliovirus does not readily generate stocks containing a measurable fraction of DI particles. The process has required $16-40$ serial passages of poliovirus at high multiplicity of infection (m.o.i.) (Cole and Baltimore 1971; McClure et al. 1980), whereas vesicular stomatitis virus, a negative-strand virus, and reovirus, a double-stranded RNA virus, can generate abundant DI particles after only three or four serial high m.o.i. passages (Nonoyama et al. 1970; Stampfer et al. 1971). For poliovirus, the strong requirement to translate the CTR region in cis means that many deletion, frameshift, and nonsense mutations in the CTR region will be selected against, and, 5' to, the CTR region; only mutations that do not disrupt the reading frame will be able to propagate efficiently. Because DI particles can interfere with the replication of wild-type viruses (Cole and Baltimore 1971), there could be a substantial selective pressure for RNA viruses to evolve a mechanism of RNA synthesis that depends on translation in cis.

Evidence suggesting a requirement for translation in cis has also been reported for other positive-strand RNA viruses. Data in which nonsense and frameshift mutations prevented RNA replication even in the presence of helper genomes have also been reported for mouse hepatitis virus (de Groot et al. 1992), clover yellow mosaic virus (White et al. 1992), cowpea mosaic virus (van Bokhoven et al. 1993), and turnip yellow mosaic virus (Weiland and Dreher 1993), although in none of these studies were possible effects of mutations on RNA sequence and structure excluded. Nevertheless, several other cytoplasmic positive-strand RNA viruses that can, 
like poliovirus, use the same RNA molecules both as a mRNA and as a template for negative-strand synthesis, might also employ a cis requirement for translation. This form of late proofreading may help many RNA viruses, whose RNA-dependent RNA polymerases are notoriously error prone (Drake 1993), to be less burdened by defective genomes than they would be without coupling between translation and RNA synthesis.

\section{Materials and methods}

\section{Cell lines and viruses}

HeLa and CVI cells were grown and plaque assays with type-1 Mahoney poliovirus were performed as described (Kirkegaard and Nelsen 1990). BTS-1, supD12A, and BSC-40supD12 cells, derived from monkey kidney, were maintained as described / $\mathrm{Se}$ divy et al. 1987) for BSC-40supD cells, except G418 $(550 \mu \mathrm{g} / \mathrm{ml})$ was added to the medium in every fourth passage of supD12A cells. All plaque assays in these three cell lines were incubated at $32.5^{\circ} \mathrm{C}$ for $40 \mathrm{hr}$ for wild-type and $80 \mathrm{hr}$ for amber mutant viruses. To derive the supD12A cell line, BSC-40supD12 cells were plated at low density to allow the formation of colonies from single cells. Eighteen cell lines grown from these colonies were screened; one cell line, designated supD12A, consistently allowed 2A-am66 to form clearly visible plaques.

\section{DNA procedures}

Nucleotides 2641-3987 of the poliovirus cDNA were cloned into pBluescript II KS(+) DNA (Stratagene), resulting in pBlue2641-3987. Site-directed mutagenesis (Kunkel 1985), to create the $2 \mathrm{~A}$-am 66 mutations, used the mutagenic oligonucleotide tgtactactgcgagtagagaaagaaatactac. Each of two independent isolates were sequenced, and the fragment containing nucleotides 2641-3987 of poliovirus cDNA was reconstructed into a plasmid containing the full-length poliovinus cDNA, T7polio (Sarnow 1989), resulting in plasmids T7-2A66-2 and T72A66-7. Transcripts from T7-2A66-2 and T7-2A66-7, upon transfection, gave rise to viruses with indistinguishable phenotypes. The 3D-am28 mutation (Sedivy et al. 1987) was reconstructed by inserting the $B g I I I-A c c I$ fragment of pSV2polio(am28) into T7-polio, creating $\mathrm{T} 7-\mathrm{Am} 28$. The virus bearing this mutation was originally designated rep(am28) (Sedivy et al. 1987), for this work it was termed 3D-am28 to conform with current poliovirus nomenclature.

T7-R2 was constructed from T7-polio by deleting nucleotides 1175-2957 as described (Kaplan and Racaniello 1988). T7-R23D-114 and T7-2A66-3D-114 were constructed by transferring the BstBI-MunI fragment containing the 3D-114 mutations from pMlu-AL27 (Diamond and Kirkegaard 1993) to T7-R2 and T7-R2-2A66. Plasmid pT7 RNA 18S, containing nucleotides 579-658 of human 18S rRNA, was obtained from Ambion.

\section{RNA Transfections}

T7-R2, T7-2A66-2, T7-2A66-7, T7-Am28, and T7-polio plasmids cut with $E c o$ RI were transcribed with T7 RNA polymerase in reactions containing $0.12 \mathrm{Ci} / \mathrm{mmole}\left[\alpha^{-}{ }^{32} \mathrm{P}\right] \mathrm{UTP}$. Super Select-D G50 columns (5 Prime-3 Prime, Inc.) were used to remove unincorporated nucleotides. RNA transcripts were extracted with phenol and stored suspended in ethanol. To quantify RNA yield, an aliquot of each transcription reaction was electrophoresed in an agarose gel containing $50 \mu \mathrm{M}$ aurintricarboxylic acid, aluminon grade (Aldrich). Bands containing fulllength transcript were excised and counted in a scintillation counter.

RNA transfections were performed with DEAE-dextran (average m.w. 500,000; Sigma Chemical Co.) by a modification of a method described previously (Wilson 1978). BTS-1 and supD12A cells were prepared by splitting confluent $100-\mathrm{mm}$ dishes of cells into eight $60-\mathrm{mm}$ dishes, placing the cells immediately at $32.5^{\circ} \mathrm{C}$, and incubating for $48 \mathrm{hr}$ before transfection. RNAs to be transfected were resuspended in buffer A $110 \mathrm{~mm}$ Tris at pH 8.0, 0.2 mM EDTA, $2 \mathrm{~mm}$ dithiothreitol, and $0.8 \mathrm{U} / \mu \mathrm{l}$ of RNasin). For each dish of tissue culture cells transfected, $1 \mu \mathrm{g}$ of each RNA was mixed with $190 \mu \mathrm{l}$ of TS buffer (Wilson 1978), then $10 \mu \mathrm{l}$ of DEAE-dextran at $10 \mathrm{mg} / \mathrm{ml}$ was added. BTS- 1 or supD12A cells were rinsed once with TS buffer. Each dish received $200 \mu \mathrm{l}$ of transfection mixture, was incubated at room temperature for $15 \mathrm{~min}$ with occasional shaking, and rinsed with TS; $4 \mathrm{ml}$ of culture medium was added, and plates were incubated at $32.5^{\circ} \mathrm{C}$ for the indicated times. The cells were harvested and virus stocks prepared as described (Kirkegaard and Baltimore 1986).

To prevent secondary infections started by progeny virus from interfering with quantification of virus from the first cycle of infection, the lengths of the first cycles of infections initiated with wild-type, 3D-am28 and 2A-am66 RNAs were measured. Neither extracellular 3D-am28 nor 2A-am66 virus was detected before $12 \mathrm{hr}$ post-transfection of either BTS-1 or supD12A cells; there is a 5- to 6-hr lag after extracellular virus starts secondary infections before amber mutant progeny virus can be detected (not shown). Because intracellular virus levels were highest at $14 \mathrm{hr}$ post-transfection, both $3 \mathrm{D}$-am 28 and $2 \mathrm{~A}$-am 66 viruses were harvested at this time. Extracellular wild-type virus first appeared at 7-8 hr post-transfection, and intracellular virus reached maximum levels at $10 \mathrm{hr}$; therefore, wild-type virus was harvested $10 \mathrm{hr}$ post-transfection.

The extent of rescue of amber mutant viruses by R2 RNA in nonsuppressing cells was determined from the ratio of the amber mutant virus yield in BTS-1 cells to the yield in supD12A cells, normalized to the RNA transfection efficiency in these two cell lines. The percentage rescue is given by $100 \times\left(\mathrm{A}_{\mathrm{BTS}} /\right.$ $\left.\mathrm{A}_{\text {sup }}\right) \times\left(\mathrm{W}_{\mathrm{BTS}} / \mathrm{W}_{\text {sup }}\right)$, where $\mathrm{A}_{\mathrm{BTS}}$ and $\mathrm{A}_{\text {sup }}$ denote the yield of amber mutant virus after transfection of amber mutant and R2 RNAs into BTS-1 and into supD12A cells, respectively, and $\mathrm{W}_{\mathrm{BTS}}$ and $\mathrm{W}_{\text {sup }}$ denote the yield of virus after transfection of wild-type and R2 RNAs into BTS-1 and into supD12A cells, respectively. This formulation factors out the effects of any RNA defects created by the amber mutations, which should be the same in BTS-1 and supD12A cells.

\section{Cotransfection efficiency}

The fraction of cells transfected with one RNA that also take up a second RNA was measured by cotransfecting wild-type RNA and R2-PvuII RNA, an inhibitor of wild-type virus replication (Kaplan and Racaniello 1988). The $99.8 \%$ reduction in wild-type virus yield observed when R2-PvuII RNA was cotransfected with wild-type RNA (Table 2) implies that at least $99.8 \%$ of cells transfected with wild-type RNA also took up R2-PvuII RNA. Transfection of poly(A) with wild-type RNA did not inhibit production of virus. Since the amber mutant RNAs and R2 helper RNA used in rescue experiments described in this work are very similar in size and sequence to wild-type RNA and R2-PvuII, the cotransfection efficiency of these RNAs was almost certainly comparably high. 
Table 2. Extent of interference of R2-PvuII RNA with the replication of wild-type RNA, used to measure cotransfection efficiency

\begin{tabular}{lc}
\hline RNA transfected & Virus yield (PFU/ml) \\
\hline Wild type & $1,090,000$ \\
& $1,150,000$ \\
Wild type + R2-PvuII & 1200 \\
& 2800 \\
Wild type + poly $(\mathrm{A})$ & $1,850,000$ \\
& $1,900,000$ \\
\hline
\end{tabular}

${ }^{a} 1.0 \mathrm{mg}$ of each of the RNAs indicated was transfected into BTS- 1 cells, harvested after incubation for $9 \mathrm{hr}$ at $37^{\circ} \mathrm{C}$, and virus stocks were titered by plaque assay on HeLa cells. Results of duplicate experiments are shown.

\section{Analysis of genetic markers in $2 A$-am66 genomes}

BTS-1 cells were transfected with R2 and 2A-am66-3D-114 RNAs (five separate transfections), with $2 A-\operatorname{am} 66$ and R2-3D114 RNAs (five transfections), and supD12A cells were transfected with 2A-am66-3D-114 RNA alone or with 2A-am66 RNA alone (one transfection each). Virus was harvested at $14 \mathrm{hr}$ post-transfection, and a single amber mutant virus isolate from each transfection was plaque-purified twice on supD12A cells. supD12A cells were infected with the resulting virus; after $24 \mathrm{hr}$ growth at $32.5^{\circ} \mathrm{C}$, cells were harvested and cytoplasmic RNAs prepared. RNase protection was performed with a probe complementary to nucleotides $7056-7388$ of the positive strand.

\section{RNA stability assays}

Virus infections were performed on BTS-1 cells at m.o.i. 5 for wild-type virus and m.o.i. 1 (defined on supD12A cells) for 3Dam 28 and $2 \mathrm{~A}$-am 66 viruses in the presence of $2 \mathrm{mM}$ guanidine hydrochloride. Following $30 \mathrm{~min}$ adsorption at ambient temperature in $\mathrm{PBS}\left({ }^{+}\right.$) with $2 \mathrm{~mm}$ guanidine, virus was removed and plates rinsed once. Medium with $2 \mathrm{mM}$ guanidine was added, and plates were incubated at $32.5^{\circ} \mathrm{C}$. Duplicate plates were harvested after $0,2,4,6$, and $8 \mathrm{hr}$ incubation. $3 \mathrm{D}$-am 28 was also tested by the same procedure in the absence of guanidine; because the frequency of revertants in the $3 \mathrm{D}$-am28 stock was $<2 \times 10^{-5}$, these revertants, even after being amplified by RNA replication, should make up only an insignificant fraction of viral RNA. Cytoplasmic RNAs were prepared and RNase protection assays performed using probes complementary to nucleotides 988-1262 of the poliovirus-positive strand, and to nucleotides 579-658 of 18S RNA. A dilution series of cytoplasmic RNAs from wild-type-infected cells was probed in parallel (not shown) to ensure that the RNase protection signals were proportional to the amounts of viral and 18S RNAs throughout the concentration range detected in this experiment. To correct for any loss of sample during the RNase protection procedure, the ratio of counts per minute $(\mathrm{cpm})$ poliovirus RNA protected to cpm 18S rRNA protected was used.

\section{RNase protection}

Two-cycle RNase protection and standard RNase protection experiments were performed as described (Novak and Kirkegaard 1991), with the following modifications. Lysis was carried out in buffer containing $10 \mathrm{~mm}$ Tris $\{\mathrm{pH} 7.5\}, 10 \mathrm{~mm} \mathrm{NaCl}, 1 \%$ NP-40, and 5 mm ribonucleoside-vanadyl complexes (New England Biolabs); following phenol extraction, EDTA was added to
$1 \mathrm{~mm}$. RNase digestion took place at $20^{\circ} \mathrm{C}$ in RNase mixture containing $300 \mathrm{mM} \mathrm{NaCl}$. For negative-strand RNase protection experiments, data from RNA standards were used to construct a standard curve (not shown), which was then used to convert cpm RNA protected from the experimental samples into relative amounts of negative-strand RNA. For detection of $18 \mathrm{~S}$ rRNA, the probe was synthesized at $5 \mathrm{Ci} / \mathrm{mmole}$ and 2.2 pmoles of probe was used for each reaction. Quantification of protected RNA was performed by two-dimensional radioanalytic quantitation (AMBIS Systems).

\section{Acknowledgments}

We thank Dr. John Sedivy for BTS-1 and BSC-40supD12 cells and for advice on their culture, and Dr. John Capone for the 3D-am28-mutant plasmid. We thank Peter Sarnow, Bill Wood, Michael Chastain, and John Doedens for helpful comments on the manuscript, and Chris Sarnowski for help with figures. This work was supported by National Institutes of Health (NIH) grant A125166 and the David and Lucile Packard Foundation. K.K. is an assistant investigator of the Howard Hughes Medical Institute. We thank the W.M. Keck Foundation for their generous support of RNA science at the University of Colorado.

The publication costs of this article were defrayed in part by payment of page charges. This article must therefore be hereby marked "advertisement" in accordance with 18 USC section 1734 solely to indicate this fact.

\section{References}

Andino, R., G.E. Rieckhof, D. Trono, and D. Baltimore. 1990. Substitutions in the protease $3 \mathrm{C}$ gene of poliovirus can suppress a mutation in the $5^{\prime}$ noncoding region. $J$. Virol. 64: 607-612.

Andino, R., G.E. Rieckhof, P.L. Achacoso, and D. Baltimore. 1993. Poliovirus RNA synthesis utilizes an RNP complex formed around the $5^{\prime}$-end of the viral RNA. EMBO $/$. 12: 3587-3598.

Baltimore, D. 1969. The replication of picornaviruses. In The biochemistry of viruses (ed. H.B. Levy), pp. 101-176. Marcel Dekker, New York.

Berkhout, B., A. Van Strien, J.H. Van Boom, J. Van Westrenen, and J. Van Duin. 1987. Lysis gene of bacteriophage NS2 is activated by translation termination at the overlapping coat gene. J. Mol. Biol. 195: 517.

Bernstein, H.D., P. Sarnow, and D. Baltimore. 1986. Genetic complementation among poliovirus mutants derived from an infectious cDNA clone. J. Virol. 60: 1040-1049.

Bienz, K., D. Egger, M. Troxler, and L. Pasamontes. 1990. Structural organization of poliovirus RNA replication is mediated by viral proteins of the P2 genomic region. J. Virol. 64: 11561163.

Caliguri, I.A. and I. Tamm. 1968. Action of guanidine on the replication of poliovirus RNA. Virology 35: 408-417.

Charini, W.A., C.C. Burns, E. Ehrenfeld, and B.L. Semler. 1991. Trans rescue of a mutant poliovirus RNA polymerase function. J. Virol. 65: 2655-2665.

Cole, C. and D. Baltimore. 1971. Defective interfering particles of poliovirus. II. Nature of the defect. I. Mol. Biol. 76: 325343.

Collis, P.S., B.J. O’Donnell, D.J. Barton, J.A. Rogers, and J.B. Flanegan. 1992. Replication of poliovirus RNA and subgenomic RNA transcripts in transfected cells. I. Virol. 66: 6480-6488.

de Groot, R.J., R.G. van der Most, and W.J.M. Spaan. 1992. The 
fitness of defective interfering murine coronavirus DI-a and its derivatives is decreased by nonsense and frameshift mutations. I. Virol. 66: 5898-5905.

Derbyshire, K.M., M. Kramer, and N.D.F. Grindley. 1990. Role of instability in the cis action of the insertion sequence IS903 transposase. Proc. Natl. Acad. Sci. 87: 4048-4052.

Dewalt, P.W. and B.L. Semler. 1989. Molecular biology and genetics of poliovirus protein processing. In Molecular aspects of picornavirus infection and detection (ed. B.L. Semler and E. Ehrenfeld), pp. 73-93. American Society for Microbiology, Washington, D.C.

Diamond, S.E. and K. Kirkegaard. 1993. Clustered charged-toalanine mutagenesis of poliovirus RNA-dependent RNA polymerase yields multiple temperature-sensitive mutants defective in RNA synthesis. J. Virol. 68: 863-876.

Drake, J.W. 1993. Rates of spontaneous mutation among RNA viruses. Proc. Natl. Acad. Sci. 90: 4171-4175.

Ehrenfeld, E., J.V. Maizel, and D.F. Summers. 1970. Soluble RNA polymerase complex from poliovirus-infected HeLa cells. Virology 40: 840-846.

Francke, B. and D.S. Ray. 1972. cis-limited action of the gene-A product of bacteriophage $\phi X 174$ and the essential bacterial site. Proc. Natl. Acad. Sci. 69: 475-479.

Giachetti, C., S.-S. Hwang, and B.L. Semler. 1992. cis-acting lesions targeted to the hydrophobic domain of a poliovirus membrane protein involved in RNA replication. I. Virol. 66: 6045-6057.

Jarvis, T.C. and K. Kirkegaard. 1992. Poliovirus RNA recombination: Mechanistic studies in the absence of selection. EMBO I. 11: 3135-3145.

Johnson, K. and P. Sarnow. 1991. Three poliovirus 2B mutants exhibit noncomplementable defects in viral RNA amplification and display dosage-dependent dominance over wildtype poliovirus. J. Virol. 65: 4341-4349.

Kaplan, G. and V.R. Racaniello. 1988. Construction and characterization of poliovirus subgenomic replicons. I. Virol. 62: $1687-1696$.

Kirkegaard, K. and D. Baltimore. 1986. The mechanism of RNA recombination in poliovirus. Cell 47: 433-443.

Kirkegaard, K. and B. Nelsen. 1990. Conditional poliovirus mutants made by random deletion mutagenesis of infectious cDNA. J. Virol. 64: 185-194.

Kitamura, N., B. Semler, P. Rothberg, G. Larsen, C. Adler, A. Dorner, E. Emini, R. Hanecak, J. Lee, S. van der Werf, C. Anderson, and E. Wimmer. 1981. Primary structure, gene organisation, and polypeptide expression of poliovirus RNA. Nature 291: 547-553.

Kleckner, N. 1990. Regulating Tn10 and IS10 transposition. Genetics 124: 449-454.

Kuge, S., I. Saito, and A. Nomoto. 1986. Primary structure of poliovirus defective-interfering particle genomes and possible generation mechanisms of the particles. I. Mol. Biol. 192: $473-487$.

Kunkel, T.A. 1985. Rapid and efficient site-specific mutagenesis without phenotypic selection. Proc. Natl. Acad. Sci. 82: 488-492.

Levintow, L., M.M. Thoren, J.E. Darnell, and J.L. Hooper. 1962. Effect of p-fluorophenylalanine and puromycin on the replication of poliovirus. Virology 16: 220-229.

$\mathrm{Li}, \mathrm{J}$.-P. and D. Baltimore. 1988. Isolation of poliovirus $2 \mathrm{C} \mathrm{mu}-$ tants defective in viral RNA synthesis. J. Virol. 62: 40164021.

McCahon, D., W.R. Slade, K.A.J. Priston, and J.R. Lake. 1977. An extended genetic recombination map for foot-and-mouth disease virus. J. Gen. Virol. 35: 555-565.

McClure, M.A., J.J. Holland, and J. Perrault. 1980. Generation of defective interfering particles in picornaviruses. Virology 100: 408-416.

Nodwell, J.R. and J. Greenblatt. 1991. The nut site of bacteriophage $\lambda$ is made of RNA and is bound by transcription antitermination factors on the surface of RNA polymerase. Genes \& Dev. 5: 2141-2151.

Nonoyama, M., Y. Watanabe, and A.F. Graham. 1970. Defective virions of reovirus. J. Virol. 6: 226-236.

Novak, J.E. and K. Kirkegaard. 1991. Improved method for detecting poliovirus negative strands used to demonstrate specificity of positive-strand encapsidation and the ratio of positive to negative strands in infected cells. I. Virol. 65: 3384-3387.

Peltz, S.W., G. Brewer, P. Bernstein, and J. Ross. 1991. Regulation of mRNA turnover in eukaryotic cells. Crit. Rev. Euk. Gene Exp. 1: 99-126.

Percy, N., W.S. Barclay, M. Sullivan, and J.W. Almond. 1992. A poliovirus replicon containing the chloramphenicol acetyltransferase gene can be used to study the replication and encapsidation of poliovirus RNA. J. Virol. 66: 5040-5046.

Pestka, S. 1971. Inhibitors of ribosome functions. Annu. Rev. Microbiol. 11: 487-562.

Sarnow, P. 1989. Role of 3 '-end sequences in infectivity of poliovirus transcripts made in vitro. J. Virol. 63: 467-470.

Sedivy, J.M. 1991. Pilot scale protein production using inducible gene amplification. In Animal cell culture and production of biologicals (ed. R. Sasaki and K. Ikura), pp. 251-258. Kluwer Academic Publishers, Netherlands.

Sedivy, J.M., J.P. Capone, U.L. RajBhandary, and P.A. Sharp. 1987. An inducible mammalian amber suppressor: Propagation of a poliovirus mutant. Cell 50: 379-389.

Spector, D.H. and D. Baltimore. 1974. Polyadenylic acid on poliovirus RNA II. Poly(a) on intracellular RNA. I. Virol. 15: 1418-1431.

Stampfer, M., D. Baltimore, and A.S. Huang. 1971. Absence of interference during high-multiplicity infection by clonally purified vesicular stomatitis virus. J. Virol. 7: 409-411.

Trono, D., R. Andino, and D. Baltimore. 1988. An RNA sequence of hundreds of nucleotides at the 5' end of poliovirus RNA is involved in allowing viral protein synthesis. J. Virol. 62: 2291-2299.

van Bokhoven, H., O. Le Gall, D. Kasteel, J. Verver, J. Wellink, and A. van Kammen. 1993. Cis- and trans-acting elements in cowpea mosaic virus RNA replication. Virology 195: 377386.

Weiland, J.J. and T.W. Dreher. 1993. Cis-preferential replication of the turnip yellow mosaic virus RNA genome. Proc. Natl. Acad. Sci. 90: 6095-6099.

White, K.A., J.B. Bancroft, and G.A. Mackie. 1992. Coding capacity determines in vivo accumulation of a defective RNA of clover yellow mosaic virus. J. Virol. 66: 3069-3076.

Wilson, J.H. 1978. Interference in SV40 DNA infections: A possible basis for cellular competence. Virology 91: 380-388.

Wimmer, E., C.U.T. Hellen, and X. Cao. 1993. Genetics of poliovirus. Annu. Rev. Genet. 27: 353-436.

Yen, T.J., P.S. Machlin, and D.W. Cleveland. 1988. Autoregulated instablility of $\beta$-tubulin mRNAs by recognition of the nascent amino terminus of $\beta$-tubulin. Nature 334: $580-585$.

Ypma-Wong, M.F., P.G. Dewalt, V.H. Johnson, J.G. Lamb, and B.L. Semler. 1988. Protein $3 \mathrm{CD}$ is the major poliovirus proteinase responsible for cleavage of the $\mathrm{P} 1$ capsid precursor. Virology 166: 265-270. 


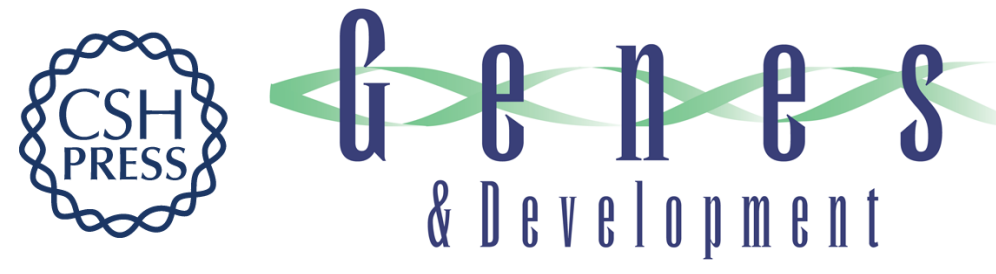

\section{Coupling between genome translation and replication in an RNA virus.}

J E Novak and K Kirkegaard

Genes Dev. 1994, 8:

Access the most recent version at doi:10.1101/gad.8.14.1726

References This article cites 47 articles, 25 of which can be accessed free at:

http://genesdev.cshlp.org/content/8/14/1726.full.html\#ref-list-1

\section{License}

Email Alerting

Service

Receive free email alerts when new articles cite this article - sign up in the box at the top right corner of the article or click here.

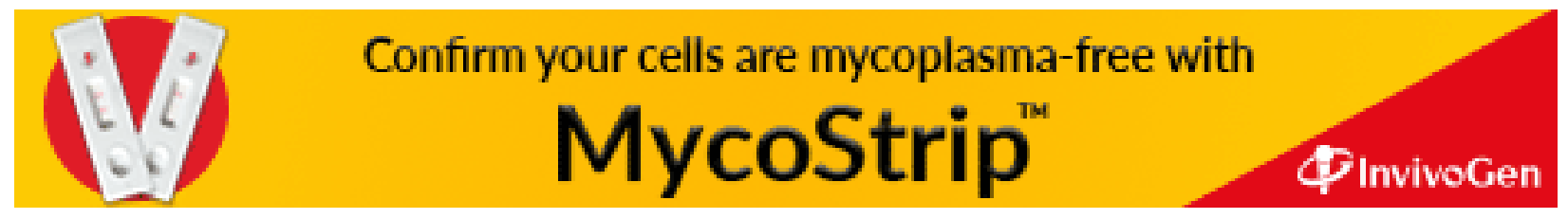

